\title{
AVALIAÇÃO DA PERDA DA TOLERÂNCIA À DESSECAÇÃO E DA QUANTIDADE DE DNA NUCLEAR EM SEMENTES DE Peltophorum dubium (SPRENG.) TAUBERT DURANTE E APÓS A GERMINAÇÃO' ${ }^{1}$
}

\author{
CRISTIANE CARVALHO GUIMARÃES ${ }^{2}$, JOSÉ MARCIO ROCHA FARIA ${ }^{3}$, \\ JULIO MAIA OLIVEIRA4 ${ }^{4}$, EDVALDO APARECIDO AMARAL DA SILVA ${ }^{5}$
}

\begin{abstract}
RESUMO - O presente trabalho teve por objetivo a avaliação da perda da tolerância à dessecação (TD) em sementes de Peltophorum dubium durante e após a germinação. As sementes foram colocadas para germinar e, ao atingirem 1, 3 e $5 \mathrm{~mm}$ de raiz primária ( $68 \%$ de umidade), foram desidratadas em sílica gel, até atingirem o grau de umidade inicial (8\%), sendo em seguida reidratadas e avaliadas quanto à sobrevivência (retomada do crescimento e formação de plântulas normais). Procedimento semelhante foi adotado para os ensaios realizados durante a embebição, onde foram amostradas 100 sementes divididas em quatro repetições de 25 para cada um dos seguintes tempos de embebição: 12, 24, 48, 60 e 72 horas. Em seguida, foram selecionados diferentes pontos de interesse (12, 48 e 60 horas de embebição e raízes primárias com $1 \mathrm{~mm}$ de comprimento) para determinação da quantidade de DNA nuclear, afim de analisar possível correlação entre início do ciclo celular e perda da TD. Com relação ao comportamento de sementes germinadas submetidas à secagem e reidratação, para os três comprimentos de raízes primárias amostradas, não houve sobrevivência. Foi observada queda progressiva na sobrevivência de sementes de Peltophorum dubium relacionada ao tempo de embebição, e posterior secagem e reidratação, sugerindo que a perda da TD desta espécie acontece nos estágios iniciais da germinação, antes da protrusão da radícula. Sementes embebidas por 12 h, 24 h, 48 h, 60 h, 72 h e aquelas germinadas, com 1 mm de comprimento radicular, apresentaram índices iguais a 98\%, 93\%, 83\%, 35\%, 17\% e 0\% de sobrevivência respectivamente. Os estudos relacionados ao conteúdo de DNA nuclear não demonstram correlação entre retomada do ciclo celular e perda da TD.
\end{abstract}

Termos para indexação: DNA nuclear, ciclo celular, Peltophorum dubium.

\section{EVALUATION OF THE LOSS OF DESICCATION TOLERANCE AND NUCLEAR DNA CONTENT IN SEEDS OF Peltophorum dubium (SPRENG.) TAUBERT DURING AND AFTER GERMINATION}

\begin{abstract}
The objective of this study was to investigate the loss of desiccation tolerance (DT) in seeds of Peltophorum dubium (Sprengel) Taubert, during and after germination. P. dubium seeds were sown, removed after germination when the primary root lengths reached 1,3 and $5 \mathrm{~mm}$
\end{abstract}

${ }^{1}$ Submetido em 10/02/2010. Aceito para publicação em 03/05/2010. Parte da Dissertação de Mestrado do primeiro autor apresentada a Universidade Federal de Lavras.

2 Bióloga, Mestre em Engenharia Florestal, UFLA. criscgbiologia@ hotmail.com.

\footnotetext{
${ }^{3}$ Eng. Florestal, Dr. Professor, Departamento de Ciências Florestais, UFLA, Caixa Postal 3037,372000-000. Lavras, jmfaria@dcf.ufla.br

${ }^{4}$ Biólogo, Mestre em Engenharia Florestal, UFLA. juliomaia2@hotmail.com.

${ }^{5}$ Eng. Agrônomo, Dr. Professor, UNESP Botucatu.Caixa Postal 237, 18610-307, Botucatu-SP, amaraldasilva@fca.unesp.br
} 
(68\% water content), dehydrated in silica gel until they had reached their initial moisture content $(8 \%)$, rehydrated and evaluated for survival (resumption of growth and development of normal seedlings). This procedure was also followed in the assays during imbibition, where 4 replications of 25 seeds were subjected to 12, 24, 48, 60 and 72 hours of imbibition. Subsequently, different points were selected (12, 48 and 60 hours of imbibition and radicles $1 \mathrm{~mm}$ long) to evaluate the nuclear DNA content in order to relate the beginning of the cell cycle with the loss of DT. For the three radicle lengths sampled, there was no survival of seeds which had been dried and rehydrated. There was a progressive decrease in the survival of P.dubium seeds related to the imbibition period and subsequent drying and rehydration, suggesting that the loss of DT occurs early in germination before radicle protrusion. Seeds imbibed for 12, 24, 48, 60, 72 hours and germinated seeds with 1 mm long radicles showed $98 \%, 93 \%, 83 \%, 35 \%, 17 \%$ and $0 \%$ survival, respectively. The assays with the nuclear DNA content do not show any relationship between the resumption of the cell cycle and the loss of DT.

Index terms: Cell cycle, nuclear DNA, Peltophorum dubium.

\section{INTRODUÇÃO}

As sementes seguem três padrões quanto ao comportamento no armazenamento: ortodoxo, intermediário e recalcitrante (Roberts, 1973; Ellis et al., 1990). As sementes ortodoxas são tolerantes à dessecação (TD) a teores de água em torno de 5\% e temperaturas baixas. Sementes de comportamento intermediário não toleram desidratação abaixo de 10 a 12,5\% de teor de água, e sementes recalcitrantes são sensíveis à redução do teor de água abaixo de $20 \%$.

Deltour e Barsy (1985) sugeriram que as células são mais sensíveis ao estresse quando se encontram com seu ciclo celular ativo, ou seja, quando em processo de síntese de DNA ou de divisão celular. A síntese e replicação de DNA ocorrem durante a interfase e nesta fase existe um período de quiescência (G0) seguido de uma fase de crescimento e pré-síntese (G1), durante a qual os núcleos de células diplóides contêm um valor arbitrário de DNA (2C; referente à quantidade de DNA por núcleo). Posteriormente, a síntese de DNA ocorre durante a Fase $S$ (síntese) e por último a Fase G2, na qual os núcleos assumem conteúdo de DNA equivalentes a 4C, indicando a ocorrência de replicação de DNA em preparação para mitose (Castro e Hilhorst, 2000). Em suma, o alongamento da radícula dentro da semente ocorre como resultado da embebição e reativação do metabolismo e do ciclo celular, podendo envolver tanto expansão como divisão celular (Górnik, 1997; Castro e Hilhorst, 2004; Marcos Filho, 2005), o que por sua vez pode estar vinculado à maior sensibilidade à dessecação ou perda de tolerância à dessecação durante o progresso do processo germinativo.

Diante da dificuldade de manipulação de sementes recalcitrantes, devido a sua rápida perda de viabilidade durante o armazenamento, sementes ortodoxas germinadas vem sendo usadas em estudos relacionados à tolerância/sensibilidade à dessecação. A razão é que sementes ortodoxas em processo de germinação perdem a tolerância à desidratação, passando a se comportar como recalcitrantes. Estas semelhanças podem facilitar a realização de estudos comparativos e conferir maior flexibilidade na concepção de experimentos que visam elucidar atributos estruturais e bioquímicos associados à sensibilidade à dessecação e comportamento durante o armazenamento (Faria et al., 2005).

A espécie em estudo, Peltophorum dubium (Spreng.) Taubert pertence à família Leguminosae subfamília Caesalpinioideae. É uma espécie arbórea nativa do Brasil conhecida popularmente como canafístula, tamboril bravo, guarucaia, angico amarelo, dentre outros. Ocorre naturalmente em regiões da Bahia, Rio de Janeiro, Minas Gerais e Mato Grosso do Sul até o Paraná (Lorenzi, 1992). Suas sementes são ortodoxas, podendo assim, serem utilizadas como ferramenta para o estudo da sensibilidade à dessecação. 
Sabendo-se da necessidade de novos estudos para um maior entendimento dos processos fisiológicos envolvidos na sensibilidade à dessecação de sementes, objetivou-se com esse trabalho avaliar a perda da tolerância à dessecação em sementes de Peltophorum dubium, durante e após a germinação, e sua possível relação com o conteúdo de DNA nas células da radícula durante a embebição, como parâmetro indicativo do nível de atividade do ciclo celular.

\section{MATERIAL E MÉTODOS}

Material vegetal: A coleta dos frutos maduros foi realizada em cinco matrizes localizadas no Campus da Universidade Federal de Lavras (UFLA), MG, sendo as sementes beneficiadas no Viveiro Florestal. O beneficiamento foi realizado manualmente, com a quebra dos frutos e uso de peneiras para separação das sementes. Após este procedimento, para retirada de impurezas presentes na amostra, foram utilizados sopradores da marca South Dakota e General. Os experimentos foram realizados no Laboratório de Sementes Florestais, do Departamento de Ciências Florestais, da UFLA.

Determinação do grau de umidade: O grau de umidade das sementes foi determinado pelo método de estufa a $103 \pm 2{ }^{\circ} \mathrm{C}$, por 17 horas (Brasil, 2009), com 4 repetições de 10 sementes $(22 \mathrm{~g})$ cada. O cálculo foi feito na base úmida, sendo o grau de umidade expresso em porcentagem.

Curva de embebição: Para determinar o padrão de embebição em água pelas sementes, a umidade inicial foi determinada como descrito anteriormente, e as curvas elaboradas utilizando-se duas repetições com 10 sementes cada, sendo cada semente pesada individualmente para determinação da evolução da hidratação. A curva foi elaborada considerando-se sementes com e sem quebra de dormência, para comparação do padrão de embebição em ambos os casos. A quebra de dormência foi realizada em água fervente, sendo as sementes em seguida lavadas em solução de hipoclorito de sódio em $1 \%$ por 5 minutos. Posteriormente as sementes foram colocadas para embeber em bandejas plásticas tendo como substrato duas folhas de papel mata borrão saturado com água destilada e acondicionado em germinadores regulados em $25{ }^{\circ} \mathrm{C}$ e fotoperíodo 12 horas. A cada três horas as sementes foram removidas dos recipientes e pesadas em balança com precisão de 0,01 g, durante três dias, período este em que se verificou a protrusão radicular da maior parte das sementes. Para as amostras onde não foi realizada quebra de dormência tegumentar as pesagens foram realizadas a cada 24 horas, durante três dias.

Caracterização da perda da tolerância à dessecação durante e após a germinação: Para essa caracterização, as sementes também foram submetidas a tratamento para quebra de dormência tegumentar e lavadas em solução de hipoclorito de sódio, como descrito anteriormente. Em seguida, foram colocadas sobre papel umedecido com água destilada em bandejas plásticas, em germinadores (Marconi tipo MA 400) regulados a $25{ }^{\circ} \mathrm{C}$, com fotoperíodo de 12 horas (Perez et al., 1999). Foram amostradas 100 sementes divididas em quatro repetições de 25 nos tratamentos referentes ao tempo de embebição: 12 h, 24 h, 48 h, 60 h e 72 h de embebição. Nos tratamentos compostos por sementes germinadas, com raízes primárias de 1 , 3 e $5 \mathrm{~mm}$ de comprimento, foram amostradas 80 sementes, divididas em quatro repetições de 20. Em seguida as sementes foram desidratadas até atingirem o grau de umidade inicial. A desidratação foi feita em caixas tipo gerbox, vedadas com filme plástico, colocando-se as sementes sobre um telado, tendo uma camada de sílica gel ao fundo, sob a temperatura de $20{ }^{\circ} \mathrm{C}$, como definida por resultados preliminares. Durante a desidratação foram realizadas pesagens sucessivas até que o peso encontrado coincidisse com o peso desejado, correspondente ao grau de umidade, por meio da expressão proposta por Cromarty et al. (1985). Após a desidratação, as sementes foram pré-umedecidas em ar úmido (100\% UR) por 24 horas em $25{ }^{\circ} \mathrm{C}$ para prevenir danos causados pela embebição (Crowe et al., 1989). Posteriormente as sementes pré-umedecidas foram reidratadas em gerbox, contendo papel de filtro saturado com água como substrato e transferidas para germinadores (Marconi tipo MA 400) regulados a $25{ }^{\circ} \mathrm{C}$, com fotoperíodo de 12 horas. As sementes germinadas que continuaram seu desenvolvimento e originaram plântulas normais foram consideradas tolerantes à dessecação (TD). As que não toleraram a dessecação, ou seja, não retomaram seu desenvolvimento e, portanto, não originaram plântulas normais, foram consideradas como mortas.

Quantificação do conteúdo de DNA nuclear: A partir dos dados de sobrevivência, obtidos com a avaliação da tolerância à dessecação durante e após a germinação, foram selecionados diferentes pontos de interesse para quantificação do conteúdo de DNA nuclear por citometria de fluxo, sendo eles: 12, 48, 60 horas de 
embebição e raízes com 1,0 mm de comprimento. As análises citométricas foram realizadas no Laboratório de Citogenética e Citometria Vegetal, do Departamento de Biologia Geral (DBG) da Universidade Federal de Viçosa (MG). Para estas análises foram usadas suspensões de núcleos intactos obtidos de radículas e raízes primárias de Peltophorum dubium. As amostras foram preparadas de acordo com o proposto por Carvalho et al. (2008) e analisadas em um citômetro de fluxo Partec PAS (Partec ${ }^{\circledR}$ _ Gmbh, Munster, Germany) equipado com uma fonte de laser e uma série de filtros (TK 420, TK 560). Para cada tratamento foram analisados, no mínimo, 5000 núcleos.

\section{RESULTADOS E DISCUSSÃO}

O aumento do grau de umidade das sementes (Figura 1) submetidas ao tratamento de quebra de dormência indica a evolução na absorção de água pelas mesmas seguindo o padrão trifásico proposto por Bewley e Black (1994). A umidade inicial das sementes foi de $6 \%$ e a umidade final destas chegou a níveis próximos aos $70 \%$, transcorridas 72 horas. Sabe-se que a velocidade da germinação é determinada principalmente pela absorção de água (Marcos Filho, 2005), fato este que pode ser certificado correlacionando-se a curva de embebição desta espécie com a germinação da mesma.

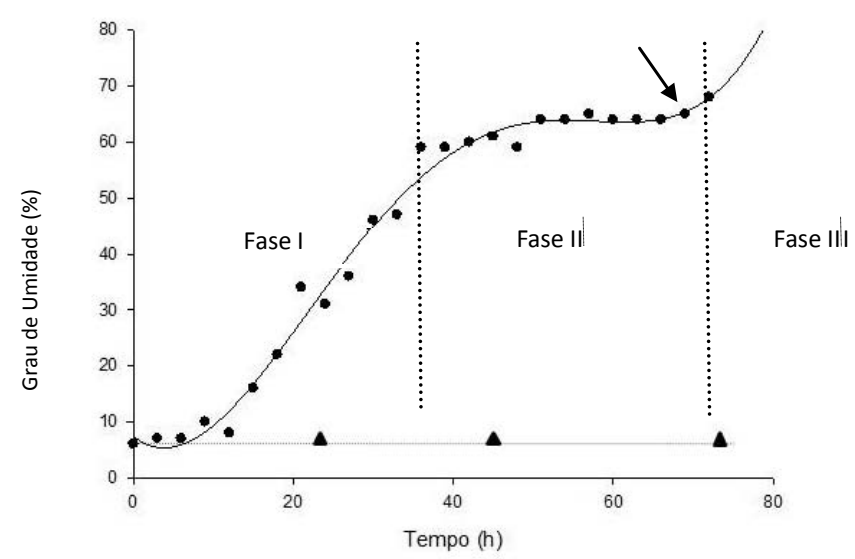

FIGURA 1. Curva de embebição de sementes de Pelthoporum dubium, com ( $\bullet$, linha inteira) e sem tratamento pré-germinativo $(\Delta)$, sob temperatura de $25^{\circ} \mathrm{C}$ e fotoperíodo de 12 horas. A seta indica 0 momento da protrusão radicular.
A curva obtida apresentou velocidade de absorção lenta nas primeiras horas da Fase I de embebição, com duração média de 36 horas, fato este que pode ser explicado pela dormência imposta pelo tegumento, comum em sementes da família Leguminosae (Bianchetti e Ramos, 1982). Embora tenha sido realizada a quebra de dormência tegumentar as sementes não foram deixadas imersas em água por 24 horas e sim por 30 minutos, o que pode ter contribuído para o atraso na absorção hídrica, devido ao lento amolecimento do tegumento. Ao final desta fase as sementes atingiram aproximadamente $60 \%$ de teor de água. Em seguida iniciou-se a Fase II, com duração de aproximadamente 35 horas, caracterizada pela redução da velocidade de hidratação indicado pelo platô observado na curva. De acordo com Bewley (1997), normalmente a Fase II dura até dez vezes mais que a Fase I. Para sementes de Pelthoporum dubium ambas as fases tiveram duração semelhante e, como citado anteriormente, esse fato pode estar relacionado à dormência imposta pelo tegumento que impede, ou dificulta, a absorção de água pelas sementes na fase I da curva de embebição. A protrusão radicular pôde ser observada, para a maioria das sementes, no início da Fase III, que começou a partir de aproximadamente 70 horas. Segundo Bewley (1997), o início desta fase é marcado pela retomada do crescimento da radícula e caracterizada pelos processos de elongação e divisão celular.

Para sementes nas quais não foi realizado o tratamento de quebra de dormência tegumentar não foi observado aumento da massa fresca, indicando que não houve absorção de água pelas mesmas. Assim, conclui-se que o amolecimento do tegumento, promovido pelo tratamento pré-germinativo, propicia uma maior absorção de água pelas sementes, resultando em aceleração e uniformização do processo germinativo.

Os resultados referentes à sobrevivência de sementes de Peltophorum dubium, com diferentes comprimentos de raízes primárias, quando submetidas à secagem em sílica gel estão dispostos na Figura 2. Foi observada alta mortalidade de sementes para os três comprimentos da raiz primária amostrados, sendo eles $1 \mathrm{~mm}, 3 \mathrm{~mm}$ e 5 $\mathrm{mm}$, indicando que mecanismos ligados à tolerância à dessecação, presentes em sementes ortodoxas maduras, são desativados ou perdidos à medida que os processos pósgerminativos avançam, contribuindo para o aumento da sensibilidade à dessecação.

Quando secas ao teor de água inicial, sementes com 1, 3 e $5 \mathrm{~mm}$ de comprimento de raiz primária mantiveram altas taxas de mortalidade $(91 \%, 96 \%$ e $100 \%)$, demonstrando 
que a perda da tolerância à desidratação acontece nos estágios iniciais de germinação de sementes desta espécie. Foi observada retomada do crescimento para uma baixa porcentagem de sementes com comprimento radicular de 1 e $3 \mathrm{~mm}$ ( $9 \%$ e $4 \%$ respectivamente), entretanto estas resultaram em plântulas anormais, fato este que ratifica os danos causados pela rápida retirada de água das sementes, propiciada pela sílica gel. Para nenhum dos comprimentos da raiz primária houve a retomada do crescimento e posterior formação de plântulas normais.

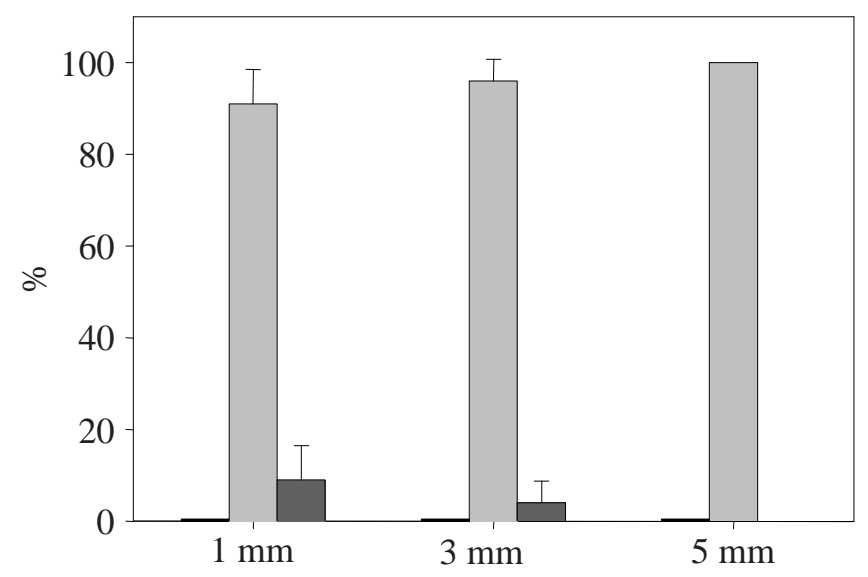

Comprimento de raiz primária $(\mathrm{mm})$

FIGURA 2. Porcentagem de sobrevivência de sementes germinadas de Peltophorum dubium, com diferentes comprimentos da raiz primária, submetidas à desidratação em sílica gel por 72 horas e subsequente reidratação. Sementes germinadas que originaram plântulas normais (coluna preta), sementes germinadas que não sobreviveram (coluna cinza claro) e sementes germinadas que originaram plântulas anormais (coluna cinza escuro).

A tolerância à dessecação é um fenômeno complexo, envolvendo a interação de ajustes metabólicos e estruturais, permitindo que as células resistam a perdas consideráveis de água sem a ocorrência de prejuízos acentuados (Marcos Filho, 2005). Quando células não tolerantes à dessecação são desidratadas, algumas conseqüências são observadas: seus solutos podem ficar mais concentrados aumentando as reações químicas destrutivas; alguns solutos podem cristalizar, inicia-se a desnaturação das proteínas e a ruptura das membranas celulares (Barbedo e Bilia, 1998); conseqüências estas que podem explicar a ausência de plântulas normais nos três comprimentos de raiz primária resultantes da germinação de sementes de Peltophorum dubium quando submetidas à secagem rápida (Figura 2).

Sabe-se que a tolerância de sementes à dessecação decresce à medida que a germinação avança, sendo inibida ou perdida geralmente a partir da protrusão radicular (Bewley e Black, 1994), podendo variar entre espécies. Como demonstrado anteriormente, sementes de Peltophorum dubium perderam a aptidão em reparar os danos causados pela secagem concomitantemente a protrusão radicular, indicando que a perda da tolerância à dessecação iniciou durante a embebição. A tolerância a desidratação nesta espécie foi gradativamente perdida com o avanço da hidratação das sementes (Figura 3).

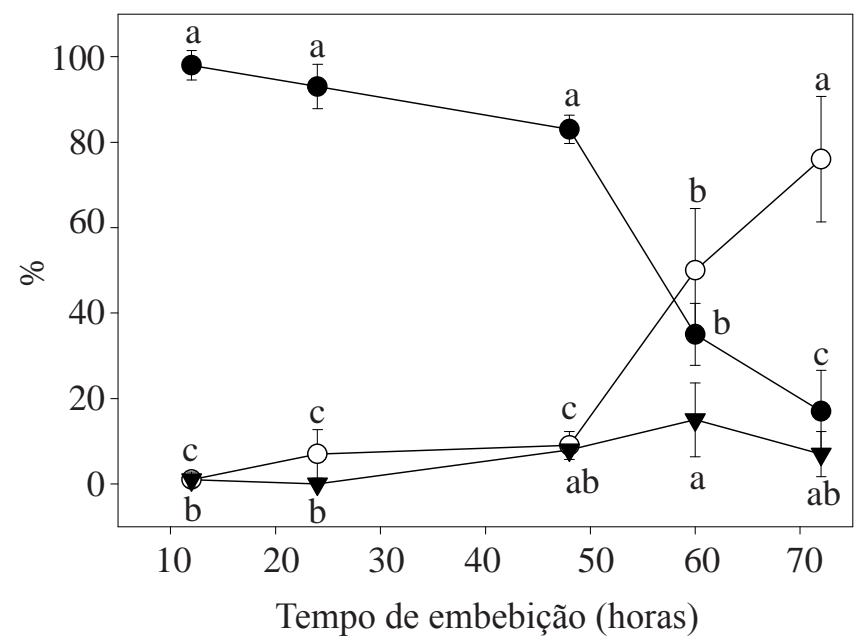

FIGURA 3. Porcentagem de sobrevivência de sementes de Peltophorum dubium, submetidas a diferentes períodos de embebição em água e posterior secagem em sílica gel por 72 horas. Sementes germinadas $(\bullet)$, Sementes mortas $(\circ)$ e Formação de plântulas anormais $(\nabla)$. As médias seguidas pela mesma letra nas linhas não diferem estatisticamente entre si aos $5 \%$ de probabilidade, pelo Teste de Tukey. 
Nos estágios iniciais da germinação (12 e 24 horas de embebição), a secagem nos níveis iniciais de teor de água (aproximadamente 10\%) não ocasionou danos às sementes, que mantiveram os índices de sobrevivência acima de 90\%. Com 48 horas, fase II de embebição, foi observada mortalidade de sementes e desenvolvimento de plântulas anormais $(9 \%$ e $8 \%$ respectivamente), porém estas ainda permaneceram com valores altos de sobrevivência (83\%). Segundo Bewley e Black (1994), a tolerância das sementes a reduções nos níveis de água decresce com o decorrer das Fases I e II de embebição, sendo perdida no início ou após a Fase III. Esta afirmação corrobora com os resultados obtidos neste experimento, onde foi observado aumento significativo da mortalidade de sementes $(76 \%)$ quando estas se encontravam na fronteira das Fases II e III (72 horas) de embebição. A fase intolerante se acentuou, portanto, com a aproximação da protrusão radicular e quando esta ocorreu, as sementes perderam integralmente a tolerância à desidratação, exibindo $100 \%$ de mortalidade. Diversos autores obtiveram resultados semelhantes no que se refere ao aumento da sensibilidade à dessecação durante a hidratação. Em experimentos com Pisum sativum (Reisdorph e Koster, 1999) e Triticum aestivum (Miazek et al., 2001) constatou-se redução na sobrevivência de sementes destas espécies quando submetidas à hidratação e posterior secagem.

As razões da conversão do estado de tolerância para o de sensibilidade à dessecação ainda não são integralmente esclarecidas, mas geralmente coincidem com o nível de atividade das células embrionárias, especialmente as da extremidade radicular. Nas sementes em processo germinativo, em geral, a radícula é a primeira estrutura a perder a tolerância à dessecação (Buitink et al., 2003). Reisdorph e Koster (1999), estudando a perda progressiva da TD em sementes germinadas de Pisum sativum, encontraram maior sensibilidade na região da raiz primária, demonstrando ser esta a primeira a sofrer danos por secagem. Assim, diversos autores obtiveram sucesso em trabalhos utilizando radículas como modelo experimental, para avaliação de alterações ocorridas durante a perda da tolerância à dessecação, dentre eles Buitink et al. (2003), Faria et al. (2005), Vieira (2008) e Masetto (2008).

Em estudos com diferentes espécies, autores verificaram baixo índice inicial e posterior incremento significativo no número de células com conteúdo $4 \mathrm{C}$ no decorrer da embebição (de Castro et al., 2000; Barrôco et al., 2005; Silva et al., 2008) e encontraram relação entre este evento e sensibilidade ao estresse, entretanto esta correlação ainda não está completamente esclarecida (Deltour e Barsy, 1985; Saracco et al., 1995). Deltour e Barsy (1985) supuseram que as células com conteúdo 2C de DNA nuclear oferecem menor susceptibilidade para fatores indutores de mutações em relação às com conteúdo 4C.

Através das análises citométricas, realizadas em radículas de Peltophorm dubium, obtidas a partir de sementes embebidas por diferentes períodos, pôde ser observado alto conteúdo de núcleos 4C (aproximadamente $40 \%$ ) durante o processo germinativo (Figura 4). Este resultado sugere que, ao final do desenvolvimento dois bloqueios ocorrem: um na fronteira entre a Fase G2 e Mitose e outro na Fase G1, mantendo as células com conteúdo 2C na fase pré- sintética, como observado em sementes de Medicago truncatula (Faria et al., 2005).

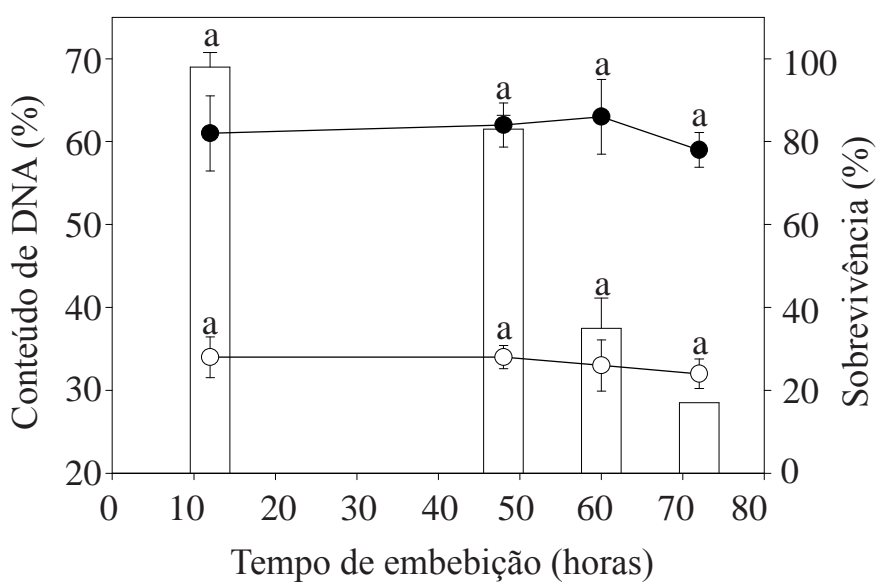

FIGURA 4. Conteúdo de DNA nuclear em radículas de sementes de Peltophorum dubium. Fração de células com conteúdo de DNA nuclear 2C (•), 4C (०) e sobrevivência de sementes embebidas e posteriormente secas e reidratadas (colunas). As médias seguidas pela mesma letra nas linhas não diferem estatisticamente entre si aos $5 \%$ de probabilidade, pelo teste de Tukey.

Em relação às sementes ortodoxas, sabe-se que a maioria das células meristemáticas está "presa” na fase 
G1, caracterizada pela ausência de sinais que favorecem a síntese de DNA (Vázquez-Ramos e Sánchez, 2003). Entretanto, foi reportado para algumas espécies, dentre elas Medicago truncatula (Faria et al., 2005) e Phaseolus vulgaris (Bino et al., 1993) elevado conteúdo 4C de DNA nuclear ao final da maturação e início da embebição. Embora tenha sido hipotetizado que células com conteúdo 4C são mais susceptíveis a possíveis mutações, e assim tornam-se mais sensíveis a estresses, dentre eles a dessecação, para algumas espécies intermediárias e recalcitrantes, como Castanea sativa (Bino et al., 1993), Inga vera (Faria et al., 2004) e Coffea arabica (Silva et al., 2008) foi amostrado elevado índice de núcleos com conteúdo 2C de DNA. A amplitude de resultados demonstra que o conhecimento dos eventos do ciclo celular, e sua importância para a germinação e tolerância a estresse, ainda são escassos e fragmentários, e que diferentes espécies podem ter desenvolvido mecanismos únicos de controle, adaptadas às características específicas de germinação e habitat (Bino et al., 1993; VázquezRamos e Sánchez, 2003; Faria et al., 2005).

Conforme citado anteriormente, em grande parte das espécies estudadas, dentre elas Capsicum annuum (Portis et al., 1999), Lycopersicon esculentum (de Castro et al., 2000) e Coffea arabica (Silva et al., 2008) foi observado aumento significativo no número de células com conteúdo 4C durante o umedecimento das sementes, indicando que estas entraram na fase de síntese de DNA concomitantemente com a hidratação. No entanto, a embebição não provoca imediata reativação do ciclo celular. Em vez disso, há um atraso de até algumas horas antes da fase $\mathrm{S}$ tornar-se evidente (Vázquez-Ramos e Sánchez, 2003). A longa transição se dá provavelmente entre a fase $\mathrm{G} 0 / \mathrm{G} 1$ devido à necessidade de recuperar danos celulares acumulados durante a maturação (Osborne, 1983). Contudo, para sementes de Peltophorum dubium não houve evidência da ocorrência da replicação de DNA durante a embebição (Figura 5), já que os níveis de $2 \mathrm{C}$ e 4C mantiveram-se inalterados.

Estes resultados demonstram que, sementes desta espécie, permanecem "presas" em determinadas fases do ciclo celular durante toda a embebição e que a perda da tolerância à dessecação e a protrusão radicular não podem ser correlacionadas ao início do ciclo celular. Faria et al. (2005), em trabalho utilizando sementes de Medicago truncatula, igualmente observaram protrusão radicular e perda da TD anteriormente a retomada do ciclo celular. Para sementes desta espécie também foi relatada constância nos índices de conteúdo 2C e 4C de DNA nuclear, durante e após a germinação, sendo observado incremento significativo no conteúdo $4 \mathrm{C}$ apenas quando as raízes primárias atingiram $3 \mathrm{~mm}$ de comprimento (dado não mostrado).

Embora seja usualmente afirmado que a protrusão radicular acontece concomitantemente à síntese de DNA, Górnik et al (1997) demonstraram que sementes de repolho (Brassica oleracea L. var. Capitata L.) exibem protrusão radicular mesmo após a incubação destas em hidroxiureia, um inibidor da Fase $\mathrm{S}$ do ciclo celular. A quantificação de DNA nuclear em células da ponta de radícula destas sementes exibiu um padrão semelhante ao das sementes secas, indicando um bloqueio total da atividade de divisão celular. Esse resultado levou à conclusão de que a replicação do DNA não é necessariamente uma condição prévia para a protrusão radicular, assim como observado no presente estudo com sementes de Peltophorum dubium.

\section{CONCLUSÕES}

Sementes de Peltophorum dubium (Spreng.) Taubert perdem a tolerância à dessecação (TD) nos estágios iniciais de germinação, assim como descrito para as demais espécies com comportamento ortodoxo. Em sementes de Peltophorum dubium foi evidenciada redução gradual da TD com o avanço da embebição e completa perda da capacidade de sobreviver à desidratação quando observada protrusão radicular. Não foi constatada, pelas análises citométricas, aumento da síntese de DNA nuclear em radículas de sementes de Peltophorum dubium durante a germinação, não sendo possível, portanto, correlacionar a retomada do ciclo celular com a perda da tolerância à dessecação. Sementes desta espécie são dispersas com alto conteúdo de DNA nuclear 4C (aproximadamente 40\%) e este índice permanece constante ao longo da embebição e com a protrusão radicular com $1 \mathrm{~mm}$ de comprimento.

\section{AGRADECIMENTOS}

À Fundação de Amparo à Pesquisa do Estado de São Paulo (FAPESP), processo 2005/04139-7, à Fundação de Amparo à Pesquisa do Estado de Minas Gerais (FAPEMIG) e ao Conselho Nacional de Desenvolvimento Científico e Tecnológico (CNPq), pelo apoio financeiro. Ao Professor Carlos Roberto de Carvalho (Universidade Federal de Viçosa), pelo apoio nas análises de citometria de fluxo. 


\section{REFERÊNCIAS}

BARBEDO, C.J.; BILIA, D.A.C. Evolution of research on recalcitrant seeds. Scientia Agrícola, v.55, p.121-125, 1998. Edição especial.

BARRÔCO, R.M.; POUCKE, K. van; BERGERVOET, J.H.W.; LIEVEN, V. de; STEVEN, P.C.; GROOT, S.P.C.; INZE, D.; ENGLER, G. The role of the cell cycle machinery in resumption of postembryonic development. Plant Physiology, v.137, n.1, p.127-140, 2005.

BEWLEY, J.D. Seed germination and dormancy. The Plant Cell, v.9, n.7, p.1055-1066, July 1997.

BEWLEY, J.D.; BLACK, M. Seeds: physiology of development and germination. 2.ed. New York: Plenum, 1994. 445p.

BIANCHETTI, A.; RAMOS, A. Comparação de tratamentos para superar a dormência de sementes de canafístula Peltophorum dubium (Spreng.) Taubert. Boletim de Pesquisa Florestal, n.4, p.91-99, 1982.

BINO, R.J.; LANTERI, S.; VERHOEVEN, H.A.; KRAAK, H.L. Flow cytometric determination of nuclear replication stage in seed tissues. Annals of Botany, v.72, n.2, p.181187, 1993.

BRASIL. Ministério da Agricultura, Pecuária e Abastecimento. Regras para análise de sementes. Ministério da Agricultura, Pecuária e Abastecimento. Secretaria de Defesa Agropecuária. Brasília, DF: Mapa/ ACS, 2009. 395p.

BUITINK, J.; VU, B.L.; SATOUR, P.; LEPRINCE, O. The re-establishment of desiccation tolerance in germinated radicles of Medicago truncatula Gaertn. Seeds. Seed Science Research, v.13, n.4, p.273-286, 2003.

CARVALHO, C.R.; CLARINDO, W.R.; PRAÇA, M.M.; ARAÚJO, F.S.; CARELS, N. Genome size, base composition and karyotype of Jatropha curcas L., an important biofuel plant. Plant Science, v.174, n.6, p.613617, 2008.

CROMARTY, A.S.; ELLIS, R.H.; ROBERTS, E.H. Design of seed storage facilities for genetic conservation. Rome: IPGRI, 1985. 100p.

CROWE, J.H.; CROWE, L.M.; HOEKSTRA, F.A. Phase transitions and permeability changes in dry membranes during rehydration. Journal of Bioenergetics and Biomembranes, v.21, n.1, p.77-91, 1989.

de CASTRO, R.D. de.; HILHORST, H.W.M. Embebição e reativação do metabolismo. In: FERREIRA, A.G.;
BORGHETTI, F. Germinação: do básico ao aplicado. Porto Alegre: Artmed, 2004. p.149-162.

DELTOUR, R.; BARSY, T. Nuclear activiation during early germination of the higher plant embryo. Journal of Cell Science, v.75, n.1, p.43-83, 1985.

ELLIS, R.H.; HONG, T.D.; ROBERTS, E.H. An intermediate category of seed storage behaviour?: I., coffee. Journal of Experimental Botany, v.41, n.230, p.11671174, Sept. 1990.

FARIA, J.M.R.; BUITINK, J.; LAMMEREN, A.A.M.V.; HILHORST, H.W.M. Changes in DNA and microtubules during loss and re-establishment of desiccation-tolerance in germinating Medicago truncatula seeds. Journal of Experimental Botany, v.56, n.418, p.2119-2130, 2005.

FARIA, J.M.R.; LAMMEREN, A.A.M.V.; HILHORST, H.W.M. Desiccation sensitivity and cell cycle aspects in seeds of Inga vera subsp. affinis. Seed Science Research, v.14, n.2, p.165-178, 2004.

GÓRNIK, K.; CASTRO, R.D. de; LIU, Y.; BINO, R.J.; GROOT, S.P.C. Inhibition of cell division during cabbage (Brassica oleracea L.) seed germination. Seed Science Research, v.7, n.4, p.333-340, 1997.

LORENZI, H. Árvores brasileiras: manual de identificação e cultivo de plantas arbóreas nativas do Brasil. Nova Odessa: Plantarum, 1992. 352p.

MARCOS FILHO, J. Fisiologia de sementes de plantas cultivadas. Piracicaba: Fealq, 2005. 495p.

MASETTO, T.E. Restabelecimento da tolerância à dessecação em sementes germinadas de Sesbania virgata e Cedrela fissilis. 2008. 82f. Tese (Doutorado em Engenharia Florestal) - Universidade Federal de Lavras, Lavras. 2008.

MIAZEK, A.; BOGDAN, J.; ZAGDANSKA, B. Effects of water deficit during germination of wheat seeds. Biologia Plantarum, v.44, n.3, p.397-403, 2001.

OSBORNE, D.J. Biochemical control systems operating in the early hours of germination. Canadian Journal of Botany, v.61, n.12, p.3568-3577, 1983.

PEREZ, S.C.J.G.A.; FANTI, S.C.; CASALI, C.A. Influência do armazenamento, substrato, envelhecimento precoce e profundidade de semeadura na germinação de canafístula. Bragantia, v.58, n.1, p.57-68, 1999.

PORTIS, E.; MARZACHÌ, C.; QUAGLIOTTI, L.; LANTERI, S. Molecular and physiological markers during seed development of peppers (Capsicum annuum L.): 
DNA replication and b-tubulin synthesis. Seed Science Research, v.9, n.1, p.85-90, 1999.

REISDORPH, N.A.; KOSTER, K.L. Progressive loss of desiccation tolerance in germinating pea (Pisum sativum) seeds. Physiologia Pantarum, v.105, n.2, p.266-271, 1999.

ROBERTS, E.H. Predicting the storage life of seeds. Seed Science and Technology, v.1, n.2, p.499-514, 1973.

SARACCO, F.; BINO, R.J.; BERGERVOET, J.H.W.; LANTERI, S. Influence of priming-induced nuclear replication activity on storability of pepper (Capsicum annuum L.) seed. Seed Science Research, v.5, n.1, p.2529, 1995.
SILVA, E.A.A.; TOOROP, P.E.; LAMMEREN, A.A.M. van; HILHORST, H.W.M. ABA inhibits embryo cell expansion and early cell division events during coffee (Coffea arabica 'Rubi') seed germination. Annals of Botany, v.102, n.3, p.1-9, 2008.

VÁZQUEZ-RAMOS, J.M.; SÁNCHEZ, M. de la P. The cell cycle and seed germination. Seed Science Research, v.13, p.113-130, 2003.

VIEIRA, C.V. Germinação e re-indução de tolerância a dessecação em sementes germinadas de Tabebuia impetiginosa. 2008. 98f. Tese (Doutorado em Agronomia) - Universidade Federal de Lavras, Lavras. 2008. 